\title{
Simulation of MPPT basing on the Improved Perturbation and Observation Method
}

\author{
Shenghui Wang, Jingying Hao, Yuexin Jin and Hong Zheng \\ College of Energy and Power, Shenyang Institute of Engineering, Shenyang \\ * Corresponding author: hao_jingying@163.com
}

\begin{abstract}
The operation of photovoltaic cells is influenced by the environmental temperature, irradiance and other factors, showing a typical non-linear characteristic in different external conditions. This paper studies the working characteristic of photovoltaic panels. This paper analyses the impact the temperature and light intensity put on the output current, output voltage and output power of photovoltaic battery. Photovoltaic cells are able to run on different and unique maximum power point. This paper compares and analyzes four useful MPPT methods, points out the advantage and weakness of every method in detail. This paper presents a calculation method of input and output capacitors and inductors of BOOST circuit And presents a new maximum power tracking method, the new method can fast track the maximum power point, and solve the oscillation problem.
\end{abstract}

Key words: maximum power point, MPPT, oscillation

\section{Introduction}

Photovoltaic power generation is a way of the development and utilization of solar energy, photovoltaic power generation uses photovoltaic cells converting solar energy into electricity. And with the advance of technology, photovoltaic power generation has the potential to be one of the most promising power generation technologies. However, photovoltaic cells show a typical nonlinear operating characteristic. In a photovoltaic power generation system, the photovoltaic cell should be made to work in its optimal condition to convert maximum solar energy into electrical energy. The traditional MPPT methods can be divided into closed-loop MPPT methods and opening-loop MPPT method basing on different judgment methods and criterions. Open-loop MPPT methods are based on the output characteristic curves of photovoltaic cells. Closed loop MPPT methods include perturbation and observation method, incremental conductance method, etc. Every method has its advantages and disadvantages, so we do a simple comparison of these methods, and give the applicable occasions of each method. In the end, this paper proposes an improved MPPT method. We make a simulation of the new method. The simulation results show the feasibility of the method, the method can improve the conversion efficiency.

\section{The Mathematical Model of Photovoltaic cell [1 3]}

Considering the effects of environmental temperature and light intensity on the photovoltaic cell, the mathematical model of photovoltaic cells used in this paper is:

In any solar radiation intensity $\mathrm{R}\left(\mathrm{wm}^{2}\right)$ and the ambient temperature $\mathrm{Ta}{ }^{\circ} \mathrm{C}$ conditions, the temperature of the solar cell is:

$$
T_{c}=T_{\mathrm{a}}+t_{c} R
$$

Where, $\mathrm{R}$ is the total solar radiation of the inclined surface of the PV array; tc $\left(\operatorname{degw}^{-1} \mathrm{~m}^{2}\right)$ is the temperature of coefficient of the solar cell module; 
In the reference condition, $\mathrm{I}_{\mathrm{sc}}$ is the short-circuit current, $\mathrm{V}_{\mathrm{oc}}$ is the open-circuit voltage, $\mathrm{V}_{\mathrm{m}}$ is the maximum power point voltage and $\mathrm{I}_{\mathrm{m}}$ is the maximum power point current. So, when the PV array works at the voltage $\mathrm{V}$, its corresponding current is I:

$$
\begin{gathered}
I=I_{s C}\left(1-C_{1}\left(\mathrm{e}^{\frac{V-D V}{C_{2} V O C}}-1\right)\right)+D I \\
C_{1}=\left(1-I_{m} / I_{s c}\right) \mathrm{e}^{\frac{V-D V}{C_{2} O C}} \\
C_{2}=\left(V_{m} / V_{O C}-1\right) \ln \left(1-\mathrm{I}_{\mathrm{m}} / I_{\mathrm{SC}}\right) \\
D I=\alpha \cdot R / R_{r e f} \cdot \mathrm{DT}+\left(R / R_{r e f}-1\right) I_{r e f} \\
D V=-\beta \cdot \mathrm{DT}-R_{S} \cdot D T \\
D T=T_{c}-T_{r e f}
\end{gathered}
$$

Where, Rref, Tref - solar radiation and temperature reference value of photovoltaic cell, generally taking $1 \mathrm{~kW} / \mathrm{m}^{\wedge} 2,25^{\circ} \mathrm{C}$.

$a-$ under the reference sunshine, the current changes in temperature coefficient (A $\left./{ }^{\circ} \mathrm{C}\right)$.

$\beta$ - under the reference sunshine,the voltage changes in temperature coefficient $(\mathrm{V}$ $\left./{ }^{\circ} \mathrm{C}\right)$.

$\mathrm{R}_{\mathrm{S}}$ - resistance in series, it is mainly composed of body resistance, cell surface resistance, electrode conductor resistance, the contact resistance between the electrode

\begin{tabular}{|c|c|}
\hline Name & Value \\
\hline $\begin{array}{c}\text { current at maximum power } \\
\text { point I }\end{array}$ & $5.05 \mathrm{~A}$ \\
\hline $\begin{array}{l}\text { voltage at the maximum } \\
\text { power point } \mathrm{V}\end{array}$ & $36.5 \mathrm{~V}$ \\
\hline $\begin{array}{l}\text { temperature coefficient of } \\
\text { current } \alpha\end{array}$ & $0.003832 \mathrm{~A} /{ }^{\circ} \mathrm{C}$ \\
\hline $\begin{array}{c}\text { temperature coefficient of } \\
\text { voltage } \beta\end{array}$ & $0.1466 \mathrm{~V} /{ }^{\circ} \mathrm{C}$ \\
\hline $\begin{array}{c}\text { series resistance in } \mathrm{PV} \\
\text { module } \mathrm{R}\end{array}$ & $0.669 \Omega$ \\
\hline Maximum power $\mathrm{P}$ & $184.325 \mathrm{~W}$ \\
\hline Open circuit current I & $5.4 \mathrm{~A}$ \\
\hline Open circuit voltage V & $45.4 \mathrm{~V}$ \\
\hline
\end{tabular}
and the silicon surface.

Battery plate model used in this thesis is the SAM/CEC Modules/Himin Clean Energy Holdings HG-185S

The parameters of the battery plate:

Table 1. The Parameters of the Battery Plate

In the MATLAB environment, the simulation models of photovoltaic panels basing on the former mathematical model are as follows: 


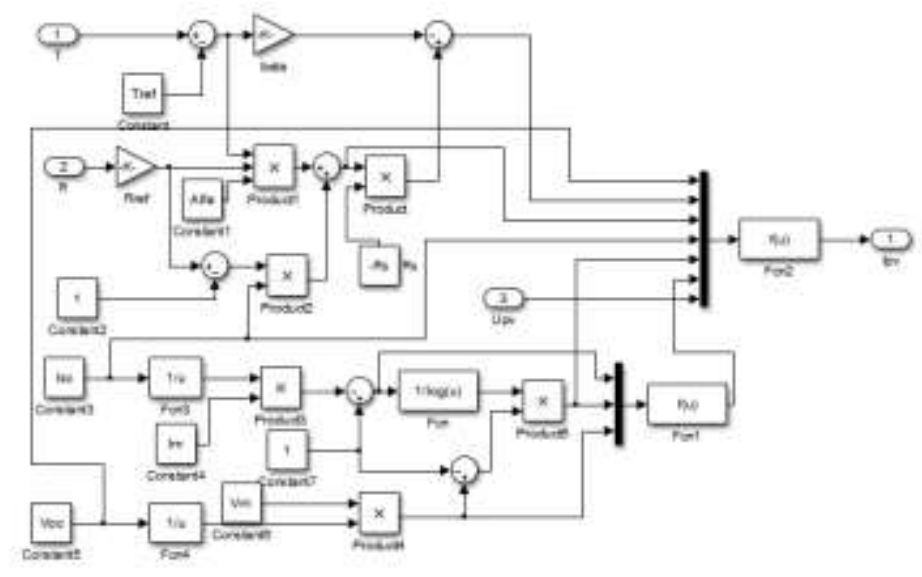

Figure 1. Mathematical Model of PV Panels in SIMULINK

Under normal conditions, the output curve of the photovoltaic cell is a curve of single peak, its extreme value point is the maximum power point. The mathematical model given by Formula (2) can accurately describe its operating characteristics. $\mathrm{I}_{\mathrm{L}}-\mathrm{U}_{\mathrm{L}}$ is the external characteristics of photovoltaic cells ,namely output characteristics, which is an important foundation of photovoltaic power generation system design. Illumination and temperature are two important parameters to determine the output characteristics of photovoltaic cells. Fixing temperature and changing illumination, or fixing illumination and changing temperature, plus ISC obtained by short circuit experiment we can get two important output characteristic of photovoltaic cells which varies with load.

Figure 2 shows $\mathrm{I}_{\mathrm{L}}-\mathrm{U}_{\mathrm{L}}$ and $\mathrm{P}-\mathrm{U}_{\mathrm{L}}$ of photovoltaic cells with irradiance and load changes, keeping the photovoltaic battery at a constant temperature.
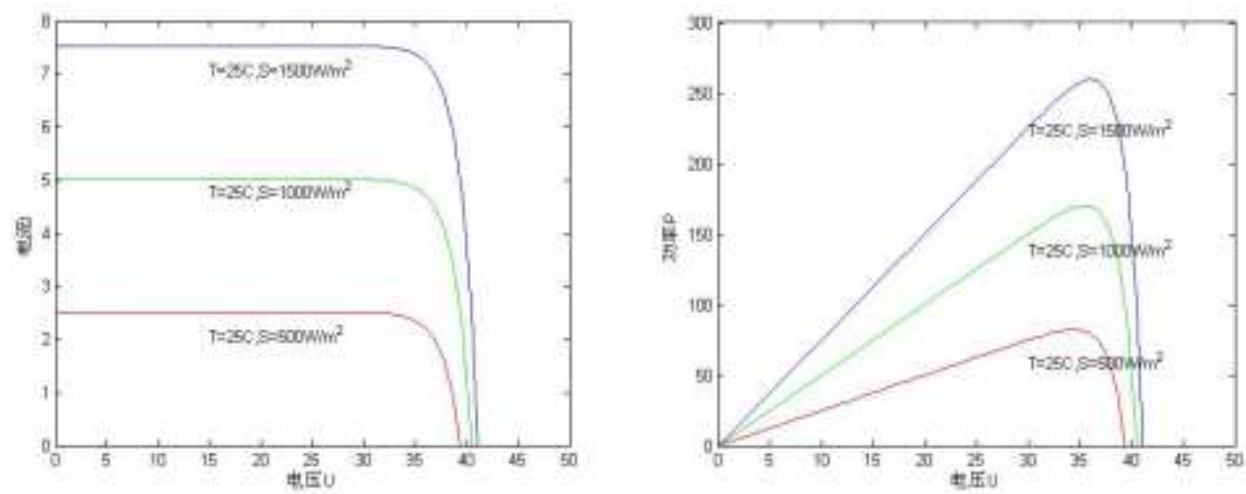

\section{Figure 2. Output Characteristic of Photovoltaic Cell at Different Sunshine Intensity}

From the curves we can see, when irradiance changes, the change of the open circuit voltage is not obvious, in contrary, the short-circuit current ISC changes a lot, the irradiance increases, the short circuit current becomes larger. The maximum power point $\mathrm{Pm}$ of $\mathrm{P}-\mathrm{U}_{\mathrm{L}}$ curves also has obvious variation along with the change of irradiance [4 7].

Figure 3 shows $\mathrm{I}_{\mathrm{L}}-\mathrm{U}_{\mathrm{L}}$ and $\mathrm{P}-\mathrm{U}_{\mathrm{L}}$ of photovoltaic cells with temperature and load changes, keeping the photovoltaic battery at a constant irradiance. From the curves we can see the open circuit voltage $\mathrm{U}_{\mathrm{OC}}$ obviously linearly changes with the change of 
temperature, short-circuit current $\mathrm{I}_{\mathrm{SC}}$ weakly varies with temperature. Pm of maximum power point varies greatly with change of temperature.
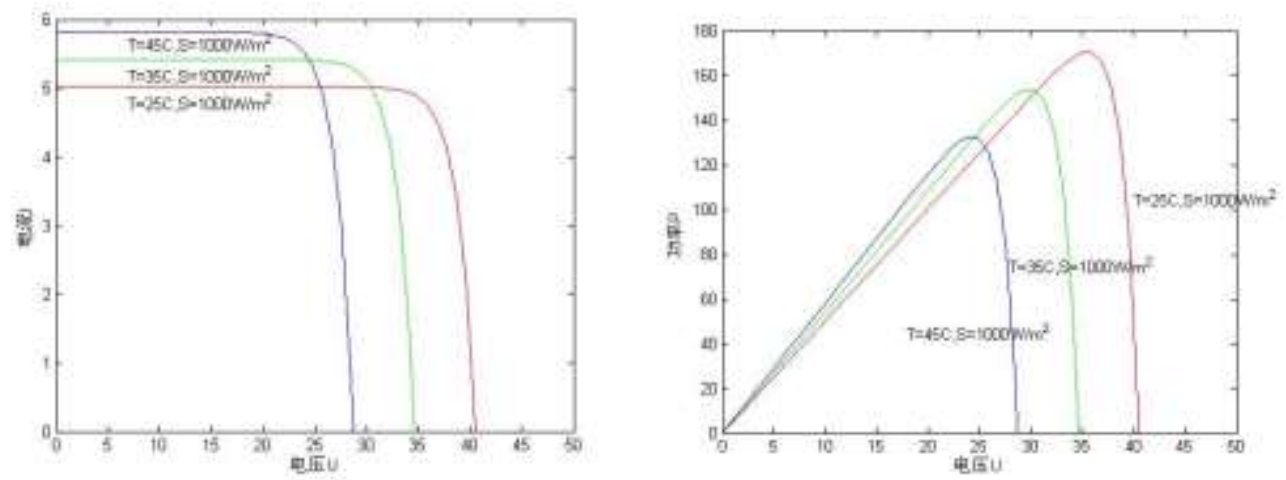

\section{Figure 3. Output Characteristic of Photovoltaic Cells under Different Temperature}

Photovoltaic cell is neither a constant current source, nor a constant voltage source, but a nonlinear dc power supply. The power the photovoltaic array generated depends on the energy provided by the sun, so the array shall not provide unlimited power for load. When the battery voltage is increased from zero by increasing the load, the output of the battery also increases from 0 ; When the voltage reaches a certain value, the maximum power can be achieved, then if the load continues to increase, the power will be gradually reduced to zero, namely voltage reaches the open circuit voltage $U_{\mathrm{OC}}$. The output power of the battery achieve the maximum value, the value is called maximum power point; the corresponding voltage of the point is called voltage of the maximum power point Um, the corresponding current of the point is called current of the maximum power point $I_{m}$, the corresponding output power of the point is called power $f$ the maximum power point $P_{m}$ I81.

\section{Comparison of Maximum Power Tracking Method}

\subsection{Constant Voltage Control Method (CVT) [9]}

(1) Principle Voltage of the maximum power point is at both sides of a fixed voltage value, which can be see from the output P-U curve principle of photovoltaic cells. CVT control method is controlling the output voltage of the photovoltaic cells in the vicinity of voltage of the maximum power point. In this case the photovoltaic cells will approximately work in the maximum power point.

(2) the advantages and disadvantages The advantage of using CVT control method is that the control method is simple and fast; the system is in high stability. But its drawback is that it ignores the impact of external conditions, it changes the voltage of photovoltaic Maximum operating point . Constant voltage tracking method is generally used in less demanding low prices and simple system.

\subsection{Short-circuit Current Proportional Coefficient Method [10]}

(1) principle There is also approximately a linear relationship between current of maximum power point of photovoltaic cells $I_{m}$ and short-circuit current of photovoltaic battery $\mathrm{I}_{\mathrm{SC}}$, namely

$$
I_{\mathrm{m}} \approx k_{2}-I_{S G}
$$

Where, the value of the coefficient $k_{2}$ depends on the characteristics of the particular photovoltaic cells. 
(2) the advantages and disadvantages The main advantage of Short-circuit current proportional coefficient method is simple and easy to implement. The disadvantages are that the photovoltaic cells are not working in the real maximum power point.

\section{3 perturbation and Observation Method $(\mathrm{P \& O})[11]$}

(1) principle The basic idea is: First, add an disturbance to the output voltage(or current)of photovoltaic cells, then observe changes in power output of photovoltaic cells, therefor change the direction of the disturbance of voltage (or current)according to the trend of the chang of the output power and the direction of the disturbance to make the system work in the maximum power point of photovoltaic cells finally.

(2) the advantages and disadvantages Perturbation and observation method has the advantages of simple control, few measured parameters. But its drawback is that the disturbance and observation method has oscillation and false judgement problem, what' s more the initial value of the voltage and the steps of disturbance voltage have great influence on the tracking accuracy and tracking speed.

\subsection{Incremental Conductance Method (INC) [12]}

(1) principle There is $\mathrm{dP} / \mathrm{dU}=0$ at the maximum power point, which can be seen from the

$\mathrm{P}-\mathrm{U}$ curves of photovoltaic cells. So consider using total differential of power to approximatly lternative $\mathrm{dP}$, the following formult can be draw from $\mathrm{dP}=\mathrm{UdI}+\mathrm{IdU}$ at the maximum power point:

$$
\mathrm{d} I / \mathrm{dU}=I / U
$$

Therefore, the formula (9) can be a basis for determining whether a photovoltaic cell are working at the maximum power point, do the corresponding control to the system, which can achieve the maximum power point.

(2) The advantages and disadvantages The advantages of INC method is a good control effect, the stability of the control method is high, and the method is not affected by the power time curve. But its drawback is that the control algorithm is complex, and has higher requirements on the control system. In addition, the incremental conductance method has misjudgment problems.

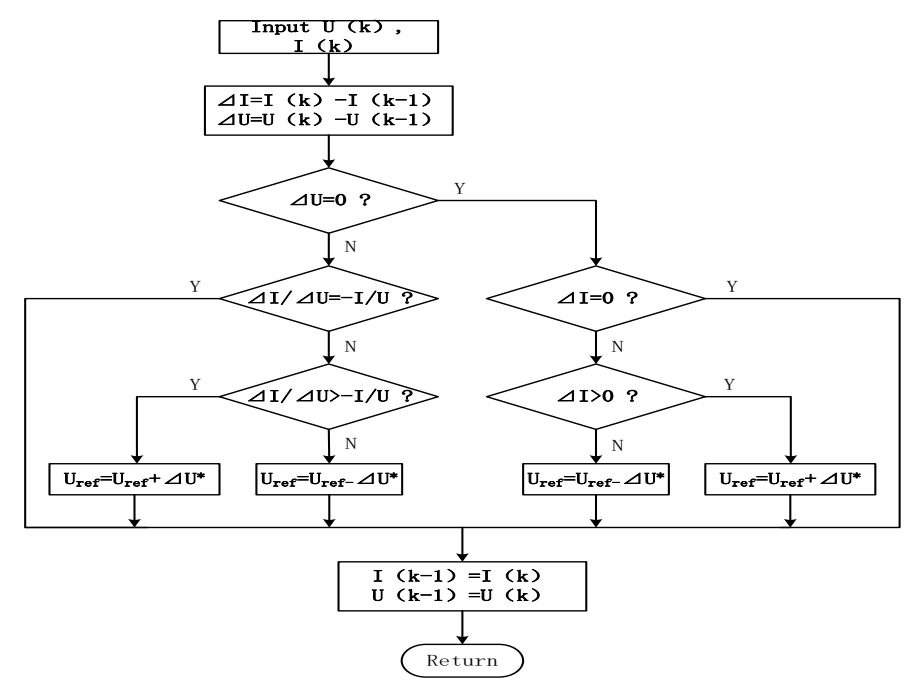

Figure 4. Flow Chart of Fixed Step Incremental Conductance Algorithm

\section{Improved Variable Step Perturbation and Observation Method}


In summary, the existing methods cannot resolve the misjudgment and oscillation problems of maximum power point tracking at one time. Now we introduce a new method of maximum power point tracking. This new method is simple and fast compared to other methods, it is very good to solve the oscillation problem, and has the effect of inhibiting the misclassification problem.

In the $\mathrm{U}-\mathrm{I}$ characteristic curves of photovoltaic cells, area range ratio of the region of class current source and the region of class voltage source is about 4:1. The perturbation and observation method with variable step size is always hoping a long step in similar constant current source region in order to improve the tracking speed, a short step size in similar constant voltage source area in order to improve the tracking accuracy. Concrete steps are: first, detect the change of the current and the voltage, judge the working area the photovoltaic cells is located in : In the class constant current source region, current changes little, in the class constant voltage source region, current changes big; then, in different work areas we set different steps. This can reduce the amount of calculation, and speed up the process of tracking maximum power point ${ }^{[13 \sim 16]}$. U1 is the voltage changed at the frist time, $\mathrm{P}_{1}$ is its corresponding output power. $\mathrm{U}$ is the current voltage, $\mathrm{P}$ is its corresponding output power.

When increasing the reference voltage $\mathrm{U}\left(\mathrm{U}_{1}=\mathrm{U}+\Delta \mathrm{U}\right)$, if $\mathrm{P}_{1}>\mathrm{P}$, it indicates that the current working point is located in the left side of the maximum power point. The system should keep increasing reference voltage, namely $\mathrm{U}_{2}=\mathrm{U}_{1}+\Delta \mathrm{U}$, where $\mathrm{U}_{2}$ is the voltage adjusted at the second time.

When increasing the reference voltage $\mathrm{U}\left(\mathrm{U}_{1}=\mathrm{U}+\Delta \mathrm{U}\right)$, if $\mathrm{P}_{1}<\mathrm{P}$, it indicates that the current working point is located in the right side of the maximum power point. At this point we should change the direction of system disturbance, reducing the reference voltage, namely $\mathrm{U}_{2}=\mathrm{U}_{1}-\Delta \mathrm{U}$, where $\mathrm{U}_{2}$ is the voltage adjusted at the second time.

When decreasing the reference voltage $\mathrm{U}\left(\mathrm{U}_{1}=\mathrm{U}-\Delta \mathrm{U}\right)$, if $\mathrm{P}_{1}>\mathrm{P}$, it indicates that the current working point is located in the right side of the maximum power point, At this point we should change the direction of system disturbance, increasing the reference voltage, namely $\mathrm{U}_{2}=\mathrm{U}_{1}+\Delta \mathrm{U}$, where $\mathrm{U}_{2}$ is the voltage adjusted at the second time.

When decreasing the reference voltage $\mathrm{U}\left(\mathrm{U}_{1}=\mathrm{U}-\Delta \mathrm{U}\right)$, if $\mathrm{P}_{1}<\mathrm{P}$, it indicates that the current working point is located in the left side of the maximum power point, The system should keep decreasing reference voltage, namely $\mathrm{U}_{2}=\mathrm{U}_{1}-\Delta \mathrm{U}$, where $\mathrm{U}_{2}$ is the voltage adjusted at the second time.

When the change of output power is very small, stop the disturbance, so this method can solve the problem of system of oscillation well.

The simulation results are as follows:

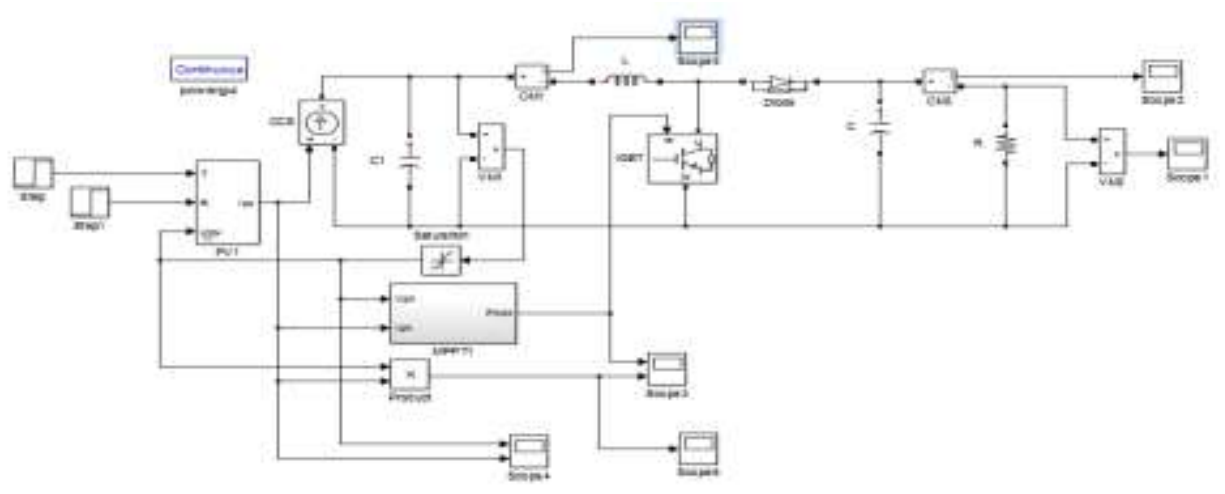

Figure 5. Model of Maximum Power Tracking System in Simulink

\section{MPPT Booster Circuit and its Parameters}


In this paper, to track the maximum power point adjusting the duty ratios of DC - DC converter. From the Angle of the efficiency of the converter, from all kinds of topology structure, the efficiency of BUCK and the BOOST circuit is the highest, BUCK-BOOST circuit, followed by, the half-bridge and full-bridge was the last, the efficiency of the application of photovoltaic systems is very important. The BOOST circuit is also the ideal choice of maximum power tracking of grid-connected system. First, it enables configuration of voltage of the DC side more flexible, the BOOST circuit is a boost converter, the peak voltage of maximum power point of $\mathrm{PV}$ array that can be lower than the AC side, through the booster of BOOST circuit before inversion. Secondly, the BOOST circuit is of high efficiency, the diode can be used to prevent energy from grid side into the photovoltaic array. Again, the energy decoupling is in output end of BOOST circuit, so input end of BOOST circuit, namely the output of the PV array, can reduce fluctuation by control means, to improve the accuracy of maximum power point tracking. of BOOST circuit adopted in this paper is shown in Figure 6.

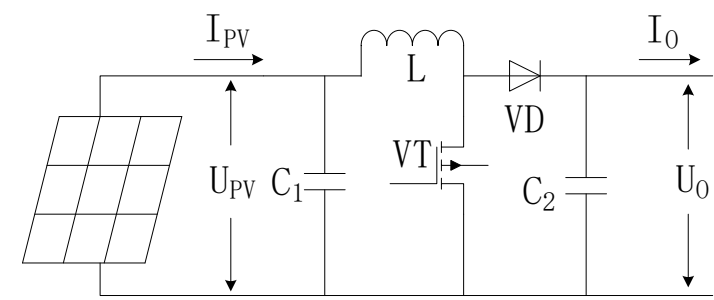

PV Array

\section{Figure 6. BOOST Circuit Topology}

The design of inductance of BOOST circuit [17]

The BOOST circuit this paper adopted works in continuous conduction mode, what can be draw from the product balance principle of the inductor volt in steady state is ${ }^{[18]}$ :

$$
V_{P V} \times D T_{S}+\left(V_{P V}-V_{O}\right) \times\left(1-D T_{S}\right)=0
$$

Where, $\mathrm{V}_{\mathrm{PV}}$, output voltage of PV array;

VO, output voltage of BOOST circuit;

$\mathrm{D}_{\mathrm{TS}}$, conduction time of switch tube;

available after finishing:

$$
V_{o} / V_{P V}=1 / 1-D
$$

Assuming there is no loss, the input power is equal to the output power, that is

$$
I_{O} / I_{P V}=1-D
$$

Where, $\mathrm{I}_{\mathrm{O}}$, the average current of load;

$\mathrm{I}_{\mathrm{PV}}$, average input current of PV cells, namely current of inductor

By $\mathrm{U}_{\mathrm{PV}}=\mathrm{L}^{*} \mathrm{di} / \mathrm{dt}$

$$
\Delta I_{P V}=\frac{V_{P V} \times D T_{S}}{L}
$$

Where, $\Delta \mathrm{I}_{\mathrm{PV}}$, ripple current of inductor;

$\mathrm{L}$, input inductance.

The definition of $\eta_{\mathrm{i}}=\frac{\Delta I_{P V}}{I_{P V}}$, what can be obtained by the above is:

$$
L=\frac{(1-D)^{2} \times D \times V_{P V} \times D T_{S}}{\eta_{i} \times P_{r}}
$$


Where,Pr,output power of BOOST circuit.

The design of input capacitor of BOOST circuit [19]

In order to reduce the rush that the ripple current of inductor have on solar panels, there is a needto add a capacitor $\mathrm{C}_{1}$ to the DC-DC circuit input. The input capacitor is calculated by the following formula:

$$
C_{1}=\frac{\Delta I_{L}}{8 \times \Delta V_{P V} \times \mathrm{f}_{S W}}
$$

Where, $\Delta \mathrm{I}_{\mathrm{L}}$, peak ripple current of inductor;

$\triangle \mathrm{V}_{\mathrm{PV}}$, peak ripple voltage of inductor;

The design of output capacitor of BOOST circuit

Power exchange between AC side and DC side of PWM rectifier will bring rush to the DC side, in order to stabilize the voltage of the DC bus, suppress the harmonic of voltage, we need to join the DC supporting capacitance between AC and DC side. The main role is as follows: (1) buffer energy exchange, stabilize voltage of DC bus; (2) suppress harmonic of the voltage.

For continuous conduction mode, assuming all ripple current flowing through the diode all flows through the capacitor, while the average value flows through the load resistor [20]. Assuming that the $\mathrm{H}$ bridge inverter can be equivalent to a resistive load, bus voltages stabilize in $365 \mathrm{~V}$. From formula (13) and (15) and $\mathrm{I}=\mathrm{C}^{*} \mathrm{dV} / \mathrm{dt}$ :.

$$
\Delta V_{O}=\frac{P_{\mathrm{r}} \times D T_{S}}{C_{2} V_{0}}
$$

Where, $\Delta \mathrm{V}_{0}$, ripple voltage of capacitance;

$$
C_{2} \geq \frac{P_{\mathrm{r}} \times D T_{S}}{\eta_{V} V_{0}^{2}}
$$

Ripple current of inductor decreases with the increase of inductance $\mathrm{L}$, but the increases of inductance will affect the dynamic characteristics of the system, increase volume and cost of converter. Input capacitance and output capacitance is obtained mainly by the requirements of ripple. Similarly, the increase of input and output capacitance is beneficial to reducing the corresponding input and output voltage ripple, but, increases of capacitance value will increase cost to the system, and the increase of input and output capacitance, have great influence on the dynamic characteristics of tracking the maximum power point of photovoltaic cells。 Notably, when Boost circuit output current is discontinuous, the output current have relatively larger ripple than the input inductor current. And because of the effect that the equivalent resistance of the common capacitor (ESR) put on filter performance, the value of the output capacitor generally required more than formula (17). Select current ripple of inductor equalling to $10 \%$ of the average current input; voltage ripple of input and output is $0.5 \%$.Combining with parameters of the system, we can selete $\mathrm{L}=6 \mathrm{mH}, \mathrm{C} 1=50 \mu \mathrm{F}, \mathrm{C} 2=100 \mu \mathrm{F}$.

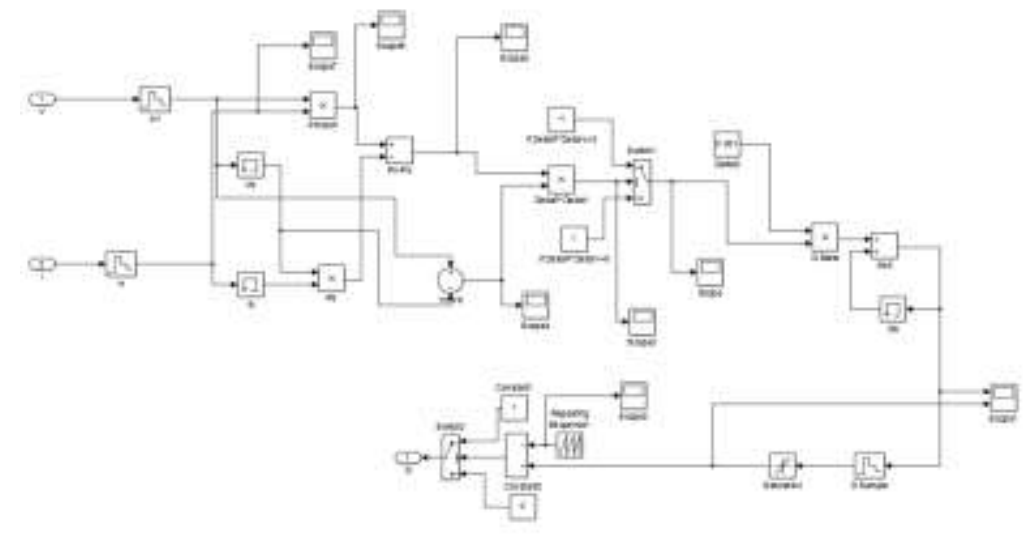


Figure 7. Maximum Power Tracking Module Model of Perturbation and Observation Method

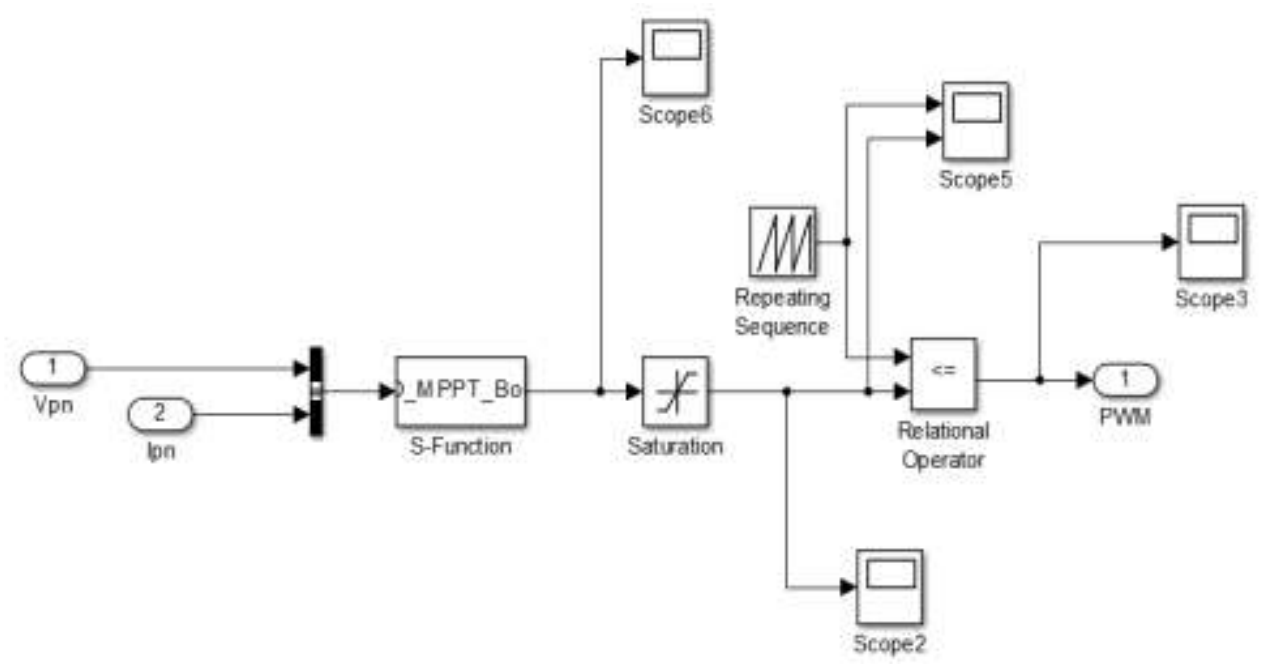

Figure 8. Maximum Power Tracking Module Model of Improved Perturbation and Observation Method

The simulation time is $0.1 \mathrm{~s}$. When $\mathrm{t}=0 \sim 0.06 \mathrm{~s}, \mathrm{~T}=25^{\circ} \mathrm{C}$, when $\mathrm{t}=0.06 \sim 0.1 \mathrm{~s}$ 时, $T=35^{\circ} \mathrm{C}$; when $\mathrm{t}=0 \sim 0.04 \mathrm{~s}, \mathrm{R}=500 \mathrm{~W} / \mathrm{m}^{\wedge}$ ^ 2 , when $\mathrm{t}=0.04 \sim 0.1 \mathrm{~s}, \mathrm{R}=1000 \mathrm{~W} / \mathrm{m}^{\wedge} 2$ 。 Ensure the voltage capacitance of $\mathrm{C} 1$ is greater than $320 \mathrm{~V}$, when the experiment begins.

The results of Variable step sized improved perturbation and observation method are as follows:

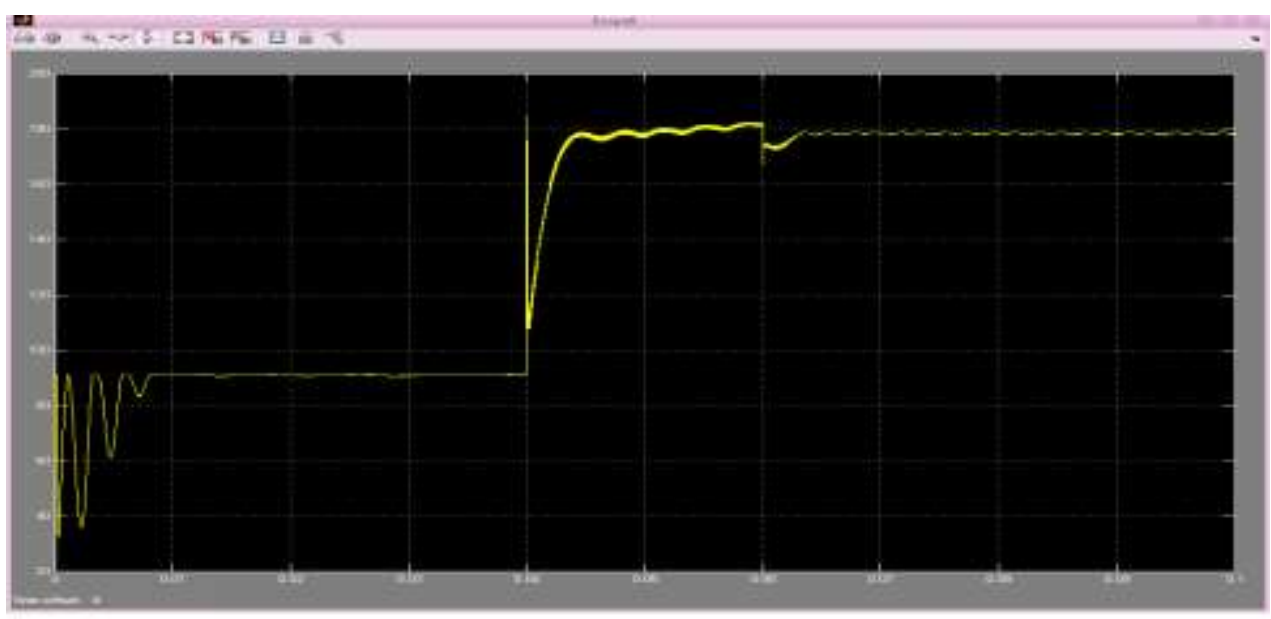

The Results of Perturbation and Observation Method are as Follows 


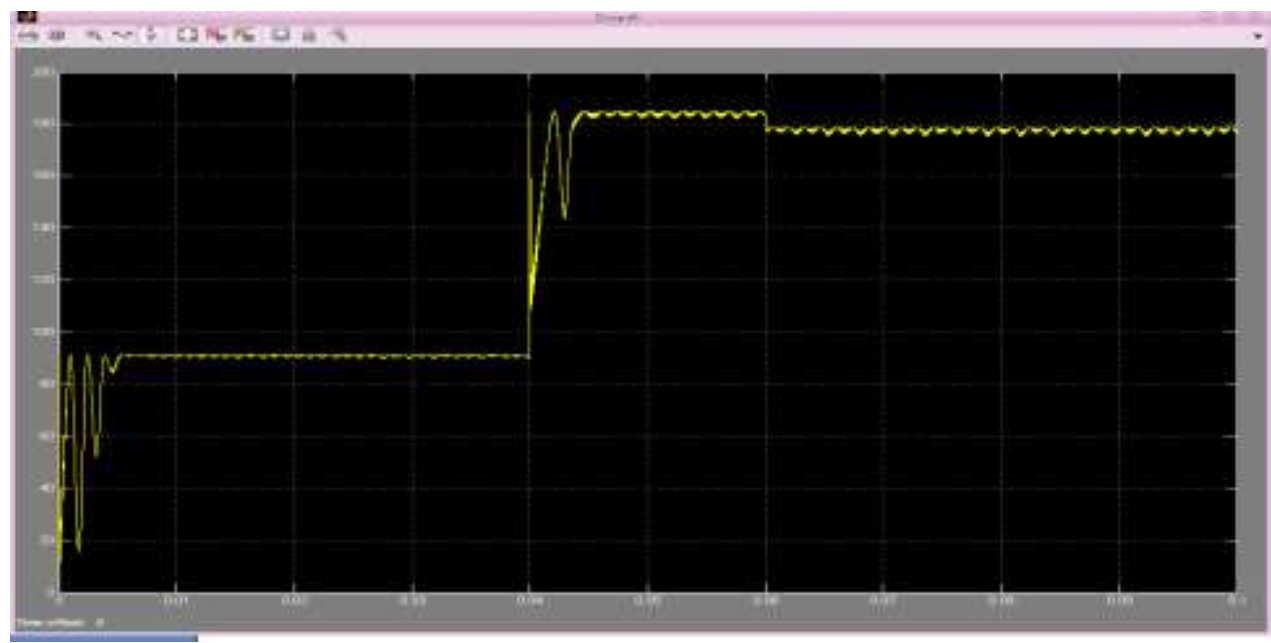

\section{Conclusion}

It is verified by simulation that improved and observation perturbation method avoids the problem of oscillation existing in the process of tracking. The method has fast tracking speed, high precision, can filter oscillation in the process of tracking, can accurately trace the maximum power point. The method provides reference and feasibility to the maximum power point of PV power.

\section{Acknowledgements}

This work is supported by National Nature Science Foundation of China under Grant 61304069, 61372195, 61371200 the Nature Science \& Foundation of Liaoning Province under Grant 2013020124, the Key Technologies R\&D Program of Liaoning Province under Grant 2012201010.

\section{References}

[1] R. A. Messenger and J. Ventre, "Photovoltaic Systems Engineering", 2nd ed.CRC Press LLC, (2004).

[2] C. G. Wang and S. Wang, "Practical photovoltaic technology", Beijing: chemical industry press, (2005).

[3] "China electrotechnical society", Electrician high-tech series: solar thermal power generation, solar photovoltaic power generation, wind power generation [M]. Beijing: Mechanical Industry Press, vol. 2, (2001).

[4] H. Y. Ding, "Research on Intelligent control of photovoltaic (pv) grid-connected generation system", Shanghai university, (2007).

[5] Y. Cui, B. H. Cai and D. Y. Li, "Research on Template simulation model of photovoltaic cells", Journal of system simulation, vol. 4, (2006).

[6] G. Walker, "Evaluating MPPT Convener Topologies Using A Matlab PV Model", Development of Computer Science and Electrical Engineering. University of Queensland, Australia.

[7] H. K. Kawamura and Y. Ishihara, "Analysis of MPPT characteristics in photovoltaic power system", Solar Energy Materials and Solar Cells, vol. 47, no. 155, (1997).

[8] K. K. Tse, M. T. Ho, Henry S.-H. Chung and S. Y. Hui, "A Novel Maximum Power Point Tracker for PV Panels Using Switching Frequency Modulation", IEEE Transactions on Power Electronics, vol. 17, no. 1227, (2002).

[9] L. Zhou and J. Wu, "The tracking control methods of the maximum power point of PV array in summary", high voltage technology, vol. 6, (2008).

[10] T. F. Long, H. X. Ding and R. H. Cai, "Comparative analysis of three point MPPT method and climbing method", popular science and Technology, vol. 8, no. 48, (2007).

[11] T. F. Long, H. X. Ding and R. H. Cai, "Theoretical analysis of three point comparison maximum power point tracking method of photovoltaic cells", Energy saving, vol. 8, no. 14, (2007).

[12] K. H. Hussein and I. Mota, "Maximum photovoltaic power tracking algorithm for rapidly changing atmospheric conditions", IEEE Proc. Generation Transmiss, vol. 59, (1995).

[13] X. F. Chen, Z. F. Cao and H. G. Xu, "Algorithm research of photovoltaic maximum power tracking", Renewable energy, vol. 1, no. 8, (2005), 
[14] F. R. Liu, S. X. Duan and F. Liu, "A Variable Step SiZ INC MPPT Method for PV Systems", IEEE, (2008).

[15] P. W. Xu, L. Liu and B. Y. Liu, "Analysises and improvements of several traditional MPPT methods of comparative", Power electronics technology, vol. 9, no. 3, (2007).

[16] M. X. Yue, "A new type of maximum power tracking method applied in the solar charger", electrical theory and new technology academic essays, (2005).

[17] M. H. Rashid and J. Y. Chen, "Handbook of power electronic technology", mechanical industry press.

[18] Z. S. Zhang, "The principle and design of switching power supply", Beijing: mechanical industry press, vol. 9, (2004).

[19] C. G. Wang and S. C. Wang, "Practical technology of Solar photovoltaic power generation", Chemical industry press, vol. $4,(\mathbf{2 0 0 5})$.

[20] D. W. Wang, "Development of 3KW photovoltaic power inverter", Tianjin University. Master Thesis, (2008).

\section{Authors}

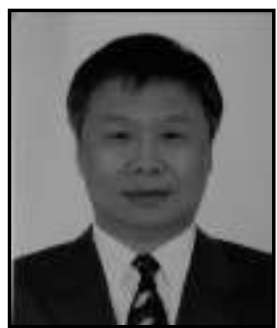

Shenghui Wang, received his PH.D degree from Shenyang University of Technology in 1999, and now is professor in Electrical Engineering department of Shenyang Institute of Engineering. His research interests include Application of PVSystems, and also electrical engineering control and automation.

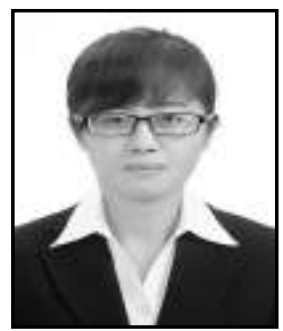

Jingying Hao, received her bachelor degree from Jiangsu University of Science and Technology in 2012, and now is doing further study in Shenyang Institute of Engineering. Her research interests include photovoltaic power generation system. 